\title{
NOTES TO THE USE OF AULACOSEIRA TAXA IN THE PALAEOECOLOGICAL RECONSTRUCTION OF THE BOHEMIAN FOREST LAKES
}

\author{
Anna Tichá ${ }^{1 *}$, Krisztina Bucz Kó ${ }^{2}$ and Václav HouK ${ }^{3}$ \\ 1*Department of Botany, Faculty of Science, Charles University, \\ Benátská2, 12801 Prague, Czech Republic; postulkova.anna@gmail.com \\ ${ }^{2}$ Department of Botany, Hungarian Natural History Museum, H-1431 Budapest, Pf. 137, Hungary \\ ${ }^{3}$ Institute of Botany of the CAS, v.v.i., Dukelská 135, 37901 Treboñ, Czech Republic
}

Tichá, A., Buczkó, K. \& Houk, V. (2017): Notes to the use of Aulacoseira taxa in the palaeoecological reconstruction of the Bohemian Forest lakes. - Studia bot. hung. 48(2): 173-188.

\begin{abstract}
Aulacoseira taxa are the most abundant members of diatom assemblages in Prášilské Lake (Czech Republic) during the Holocene. These dominant diatom taxa were studied in freshwater lacustrine sediments in order to harmonize data for subsequent diatom-based palaeoecological reconstruction. Nine taxa were distinguished within the genus, six of them $(A$. alpigena, $A$. lacustris, $A$. laevissima, $A$. lirata, $A$. perglabra, $A$. valida) showed clear features for identification, the rest three taxa (A. nivalis, $A$. pfaffiana, $A$. aff. tenella) required deeper analysis. We decided to use taxa in species rank, $A$. nivalis (W. Smith) English et Potapova and $A$. pfaffiana (Reinsch) Krammer, in spite of their hardly odds and the earlier suggested merging. Morphology of $A$. aff. tenella was also discussed in detail. Despite all endeavours, to distinguish some specimens belonging to the $A$. distans species complex using light microscope is impossible and a classification into the aggregates is needed. We suggested counting the valve face views and the valve mantle views separately, in order to repair subsequent potential misidentifications more simply.
\end{abstract}

Key words: Aulacoseira, Bohemian Forest, diatoms, palaeolimnology

\section{INTRODUCTION}

Aulacoseira Thwaites taxa represent common and often abundant component of subfossil diatom assemblages in lacustrine sediments. These freshwater centric diatoms contribute significantly also to recent diversity and production of algal communities, thus we can fall back on recent observations to reconstruct past conditions. However, this approach requires robust taxonomic background to produce reasonable results (STOERMER 2001, BIRKS 2010).

Even though Aulacoseira is thoroughly studied, identification of some taxa especially using light microscope (LM) is still ambiguous and complicated (SIVER and KLING 1997). "Low-mantle" taxa (valve mantle height:valve face diameter $<1$ ) with areolated valve face classified to Aulacoseira distans (Ehrenberg) Simonsen species complex cause especially troubles with determination and the 
revisions of previous classifications often revealed misidentifications (POTAPOVA et al. 2008, TUj 2010,2015$)$. Although autecology of each species is often similar, they sometimes differ distinctly and their separation is important for reliable environmental reconstructions as well (ENGLISH and PotAPOVA 2009, TUJi 2015).

One of the main problems with distinction is represented by couple Aulacoseira nivalis (W. Smith) English et Potapova and Aulacoseira pfaffiana (Reinsch) Krammer that are common taxa in oligotrophic lakes. To cope with them during the palaeolimnological examination is often necessary because of their prevalent abundance. Unfortunately, clear concept of its separation is still lacking and the confusion in the interpretation of type material (Tuji 2010) led to one possible approach of merging them into one taxon, as Aulacoseira nivalis (W. Smith) English et Potapova (English and Pota pova 2009, Pota pova et al. 2008, Tuji 2010). On the other hand there still exist endeavours to distinguish them in the diatom record (e. g. BUCZ Kó et al. 2010, GeNKAL and KULI KOVS KIY 2014), and the diatom guides present them as different taxa.

Research of lacustrine sediments, in which diatom analysis plays important role, comprises essential part in efforts to reveal climate and landscape dynamics. The bulk of Czech natural lakes (including Prášilské Lake) lying in the Bohemian Forest mountain range offers great possibility for high resolution, multi-proxy studies. This area was included in a detailed taxonomic work dealing with centric diatoms (Houk 2003) and Aulacoseira taxa were also reported by previous pal-

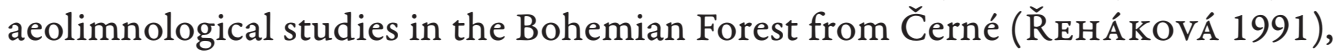
Čertovo (VeselÝ et al. 1993) and Plešné Lake (Štef KovÁ 2008).

Lacustrine sediment from Prášilské Lake provides a great opportunity to investigate morphological variability of species of the Aulacoseira distans species complex, as the preliminary examination of samples has already shown. Moreover our observations are possibly comparable with the documentation of Aulacoseira taxa from other lakes in the Bohemian Forest (Houk 2003, ŠTEF KOVÁ 2008) and therefore we can base our conclusions on broader local record.

This study was initiated with two main purposes: (i) to reveal our approach and provide some suggestions how to deal with classification of problematic Aulacoseira taxa during routine counting using LM and (ii) to harmonize the approach to the determination of selected Aulacoseira specimens in the Czech region.

\section{MATERIAL AND METHODS}

Study site

Prášilské Lake is situated in the Bohemian Forest - mountain range in southwestern Bohemia ( $49^{\circ} 4.52830^{\prime}, \mathrm{E} 13^{\circ} 24.07292^{\prime}$ ) at an altitude of $1079 \mathrm{~m}$ a. s. 1 . 
(ŠOBR and JANSKÝ 2016). It is the second smallest (water surface area $42,044 \mathrm{~m}^{2}$ ) but the third deepest (mean depth $8.3 \mathrm{~m}$, maximal depth $17.2 \mathrm{~m}$ ) basin among the eight glacial lakes located both at the Czech and German sides of the mountain range (ŠOBR and JANSKÝ 2016). Origin of the Bohemian Forest lakes was connected with glacial erosion in the last cold period, the end of glaciation there is estimated as early as before Younger Dryas (MENTLÍK et al. 2010). Lacustrine environments were strongly affected by acidification in the 20th century and now are in different stages of recovery (NEDBALOvÁ et al. 2006), their development is still monitored (VRBA et al. 2015). Prášilské Lake is an oligotrophic and slightly acidic basin such as the rest of the lakes in the area except the only mesotrophic Plešné Lake (NedBaLová et al. 2006).

\section{Sampling and data processing}

Two long cores and two gravity cores were taken from the central part of the lake in August 2015 as part of the project EUROPIA field works. Long cores (Pra-15-2-1, Pra-15-2-2) were used for this study, subsampled by $0.5 \mathrm{~cm}$ and digested following standard methodology (BATTARBEe 1986, BATTARBEe et al. 2001). Dissolution of sediment in hot hydrogen peroxide was used in order to keep frustules as untouched as possible for determination. Subsamples taken at $10 \mathrm{~cm}$ intervals were examined. Permanent mounts were created using Naphrax mounting resin and investigated using LM. Pictures were shot in two ways: (i) focused in the plain of the frustule surface in which areolae appear to be dark, in plates presented as "normal image", and (ii) focused in the plain of the holes in which areolae appear to be light, then the picture was inverted in photo editor and presented in plates as "inverted image" (Houk 2003). For scanning electron microscopy (SEM), some selected, cleaned samples were air-dried on an aluminium stub. Specimens were coated with gold-palladium using a XC7620 Mini Sputter Coater for $120 \mathrm{~s}$ at $16 \mathrm{~mA}$, and studied with a Hitachi S-2600N scanning electron microscope operated at $20 \mathrm{kV}$ and $5-8 \mathrm{~mm}$ distance.

Determination followed mainly atlases of European centric diatoms (Hou K 2003; HOUK and KLEE 2007), but other available literature was used for comparison (Buczkó et al. 2010, ENglish and Potapova 2009, Krammer 1991, Krammer and Lange-Bertalot 1991, Potapova 2014, Potapova et al. 2008, Tuji 2010, 2015, Tuji and Williams 2006).

\section{RESULTS}

We distinguished nine species of the genus Aulacoseira typical for alpine and acidic basins in the studied profiles of Prášilské Lake. Descriptions are provided 
below only for problematic taxa, all found Aulacoseira taxa are listed in alphabetical order.

\section{Enumeration}

Aulacoseira alpigena (Grunow) Krammer - Abundant, occasionally dominant species in the Prášilské Lake record, the morphology of the taxon agrees with the published details (Hou K 2003).

Aulacoseira lacustris (Grunow) Krammer - Rare species in Prášilské Lake, large celled form, its characteristics in accordance with published features (Hou K 2003).

Aulacoseira laevissima (Grunow) Krammer - Rare species, agrees in morphology with published characteristics (HOUK and KLEE 2007).

Aulacoseira lirata (Ehrenberg) R. Ross (Figs 1-3) - Rare, occasionally common species in the Prášilské Lake record. - Cells cylindrical, tightly linked into long chains; cell walls mostly thick. Valves 7-27 $\mu \mathrm{m}$ in diameter, 3-10 $\mu \mathrm{m}$ high. Valve faces \pm flat, smooth with a ring of areolae between spines at the margin, possibly with other more or less distinct, irregularly spaced pori. Linking spines at the valve face/valve mantle junction short, strong, distally spatulate. The structureless collar relatively high, distinctly separated from the areolated valve mantle with a thick ringleist, running deeply inside the frustule, with a transverse row of more distinct pori at the smooth collar/areolate valve mantle interface. Valve mantles with longitudinal, straight or slightly dextrorse rows of coarser areolae, often incomplete.

Aulacoseira nivalis (W. Smith) English et Potapova (Figs 10-18) - Rare, occasionally common species in the Prášilské Lake record. - Cells cylindrical, valves 7.5-12.8 $\mu \mathrm{m}$ in diameter, valve mantles 3.8-4.7 $\mu \mathrm{m}$ high in the material from Prášilské Lake. Valve face full of quite large areolae making a structure of a honeycomb. Valve mantle with straight or slightly dextrorse rows of rectangular areolae. Collar well developed, not separated from areolated part of the mantle by any transverse row of areolae. Internal valve mantle outlines straight with very poorly developed ringleist.

Aulacoseira perglabra (Østrup) Haworth (Figs 4-9) - Rare species in the Prášilské Lake record. - Cells low cylindrical, linked into long, but often fragmented chains, cell walls medially thick. Valves 8-17 $\mu \mathrm{m}$ in diameter, 3-4 $\mu \mathrm{m}$ high. Valve faces \pm flat, with very variable ornamentation - with the pattern composed of only one ring of coarse areolae at the valve margin to the pattern consisting of coarser puncta on the whole surface, often shaded in the valve face middle part. Spines at the valve face/valve mantle junction short, pointed, continuing from ribs between pervalvar rows of valve mantle areolae. The structureless col- 
lar relatively high, the ringleist nearly indistinguishable using LM. Internal and external valve mantle outlines parallel. Very low valve mantles with short, parallel to pervalvar axis or slightly dextrorse rows of coarse areolae, 1-2 transverse rows of areolae beneath the valve face margin distinguished using LM.
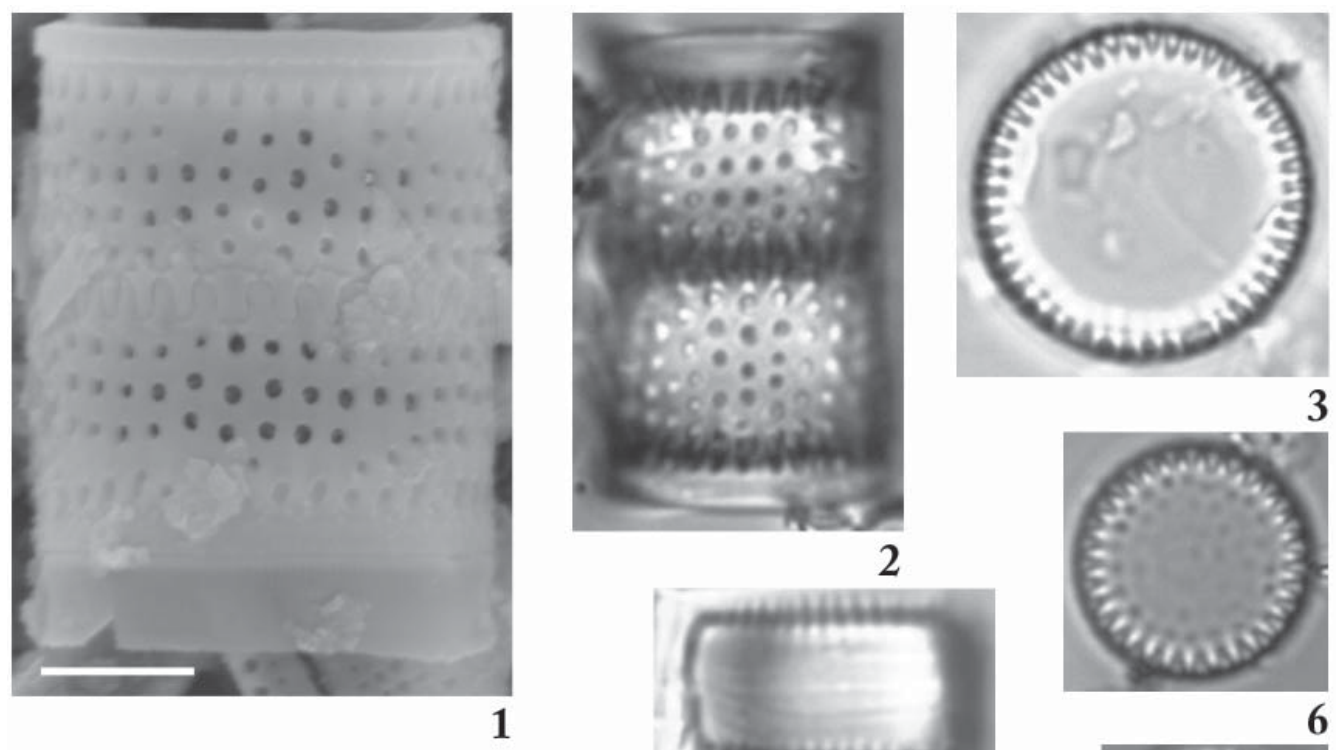

1
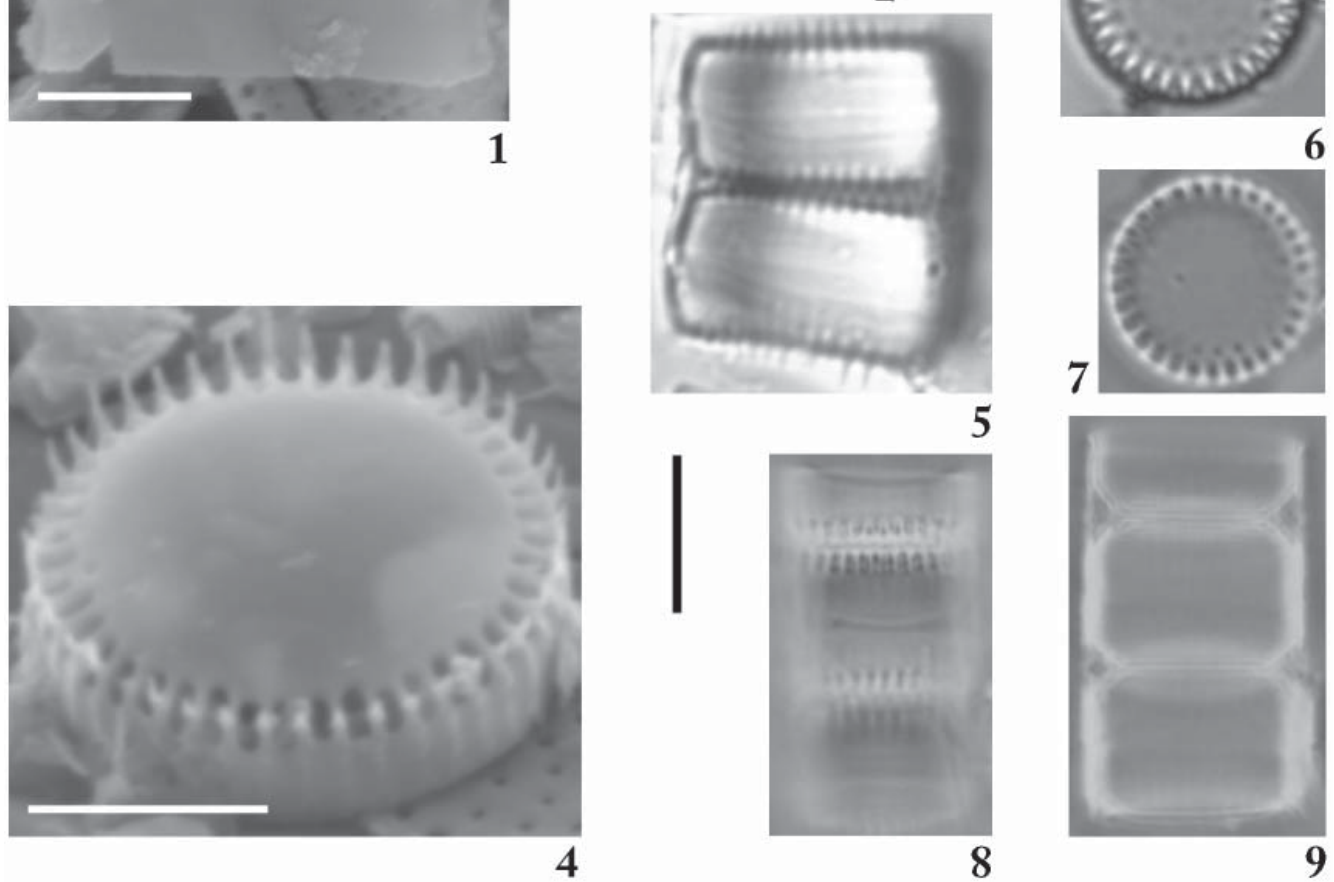

Figs 1-9. Aulacoseira lirata (Ehrenberg) Ross, Aulacoseira perglabra (Østrup) Haworth. - Figs 1-3: A. lirata: Fig.1: mantle view, SEM, s. 1630; Fig. 2: mantle view, normal image, LM, 1500×, s. 1580; Fig. 3: valve view, normal image, LM, 1500×, s. 1490; Figs 4-9: A. perglabra: Fig. 4: semi-valve view, SEM, s. 1490; Figs 5-6: normal image, LM, 1500×; Fig. 5: mantle view, s. 1490; Fig. 6: valve view, s. 1640; Figs 7-9: inverted image, LM, 1600×; Fig. 7: valve view, s. 1640; Fig. 8: mantle view, s. 1530; Fig. 9: cross section of Fig. 8; scale bars: SEM $-5 \mu \mathrm{m}, \mathrm{LM}-10 \mu \mathrm{m}$. 
Aulacoseira pfaffiana (Reinsch) Krammer (Figs 19-26) - Abundant, often dominant species in the Prášilské Lake record. - Cells cylindrical, valves 9.3$17.5 \mu \mathrm{m}$ in diameter, valve mantles 3.7-5.6 $\mu \mathrm{m}$ high in material from Prášilské Lake. Valve face covered with rounded areolae, often smaller or unclear in the
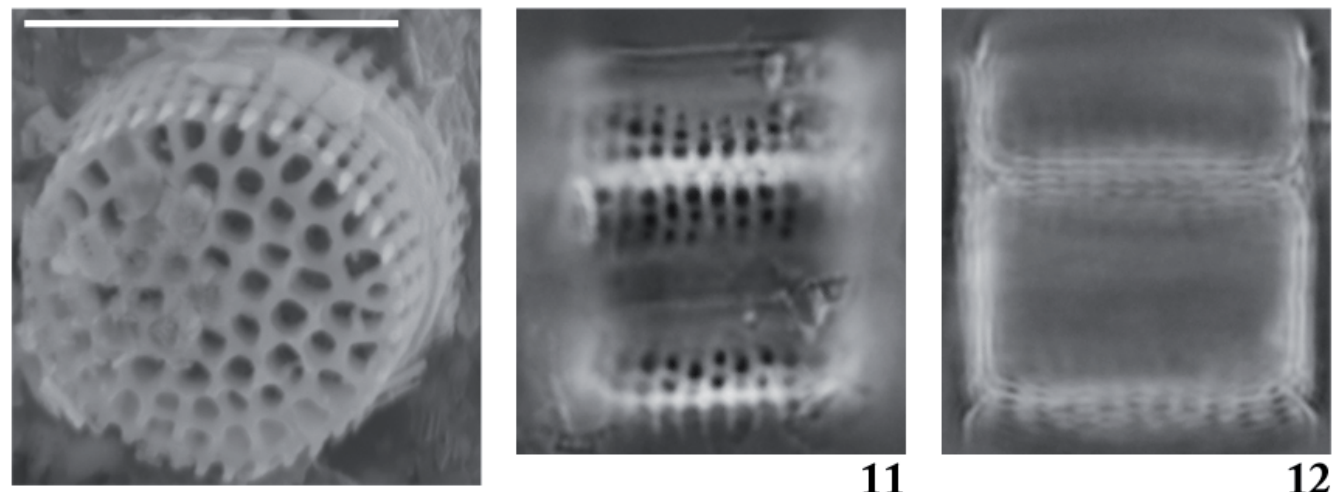

10

11

12
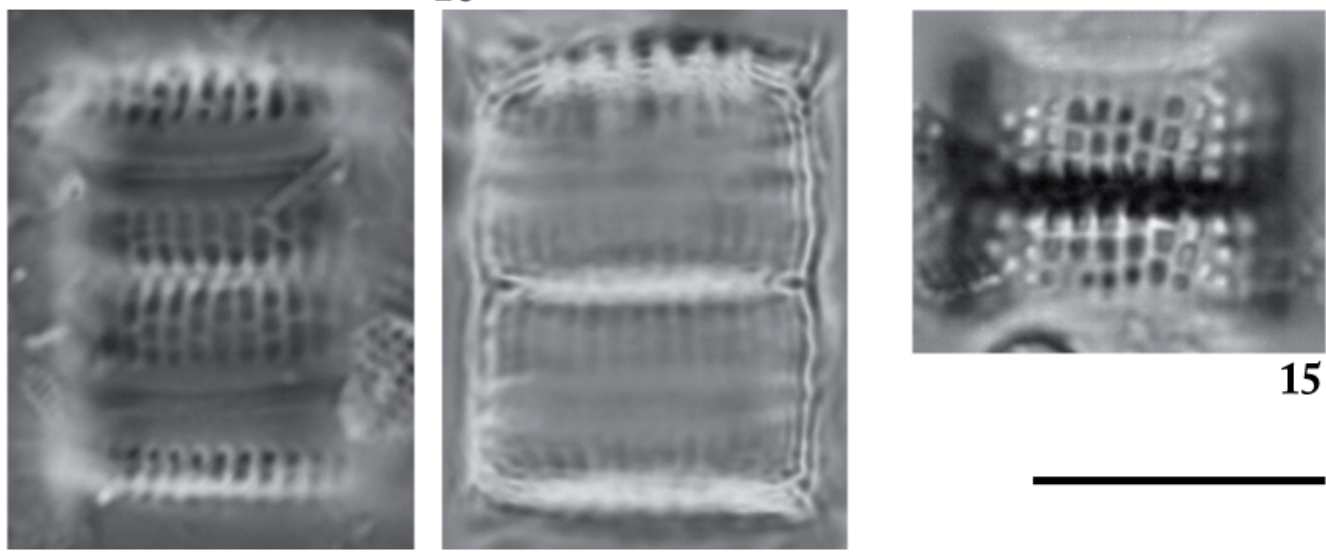

15

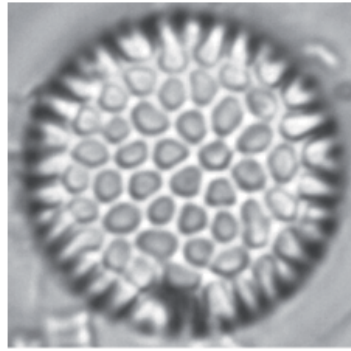

13
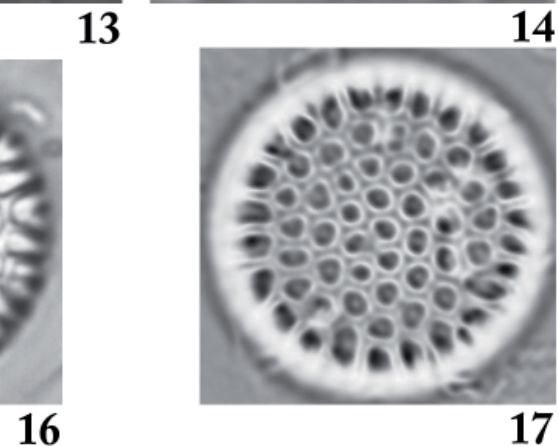

17

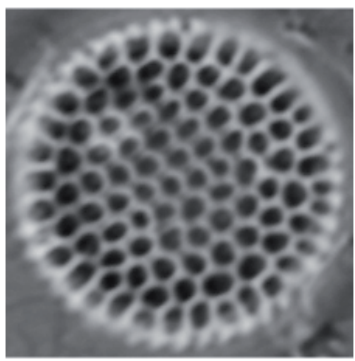

18

Figs 10-18. Aulacoseira nivalis (W. Smith) English et Potapova. - Fig. 10: valve view, SEM, s. 1590; Fig. 11-14: mantle view, inverted image, 1600×, LM, s. 1490: Fig. 12: cross section of Fig. 11; Fig. 14: cross section of Fig. 13; Fig. 15: mantle view, normal image, 1500×, LM, s. 1620; Fig. 16: valve view, normal image, 1500×, LM, s. 1490; Figs 17-18: valve view, inverted image, 1600×, LM, s. 1490; scale bars $-10 \mu \mathrm{m}$. 
valve centre. Valve face margin surrounded with distinctly elongated areolae. Valve mantle with slightly dextrorse or longitudinally straight rows of areolae. Collar well developed, not separated from areolated part of the mantle by any
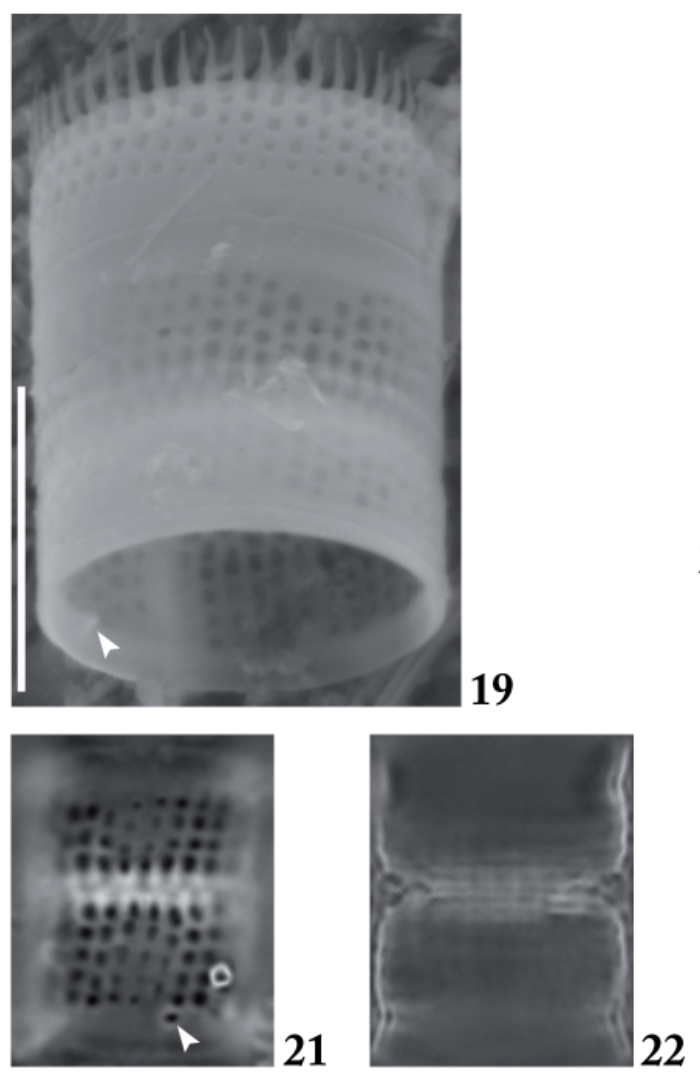

20
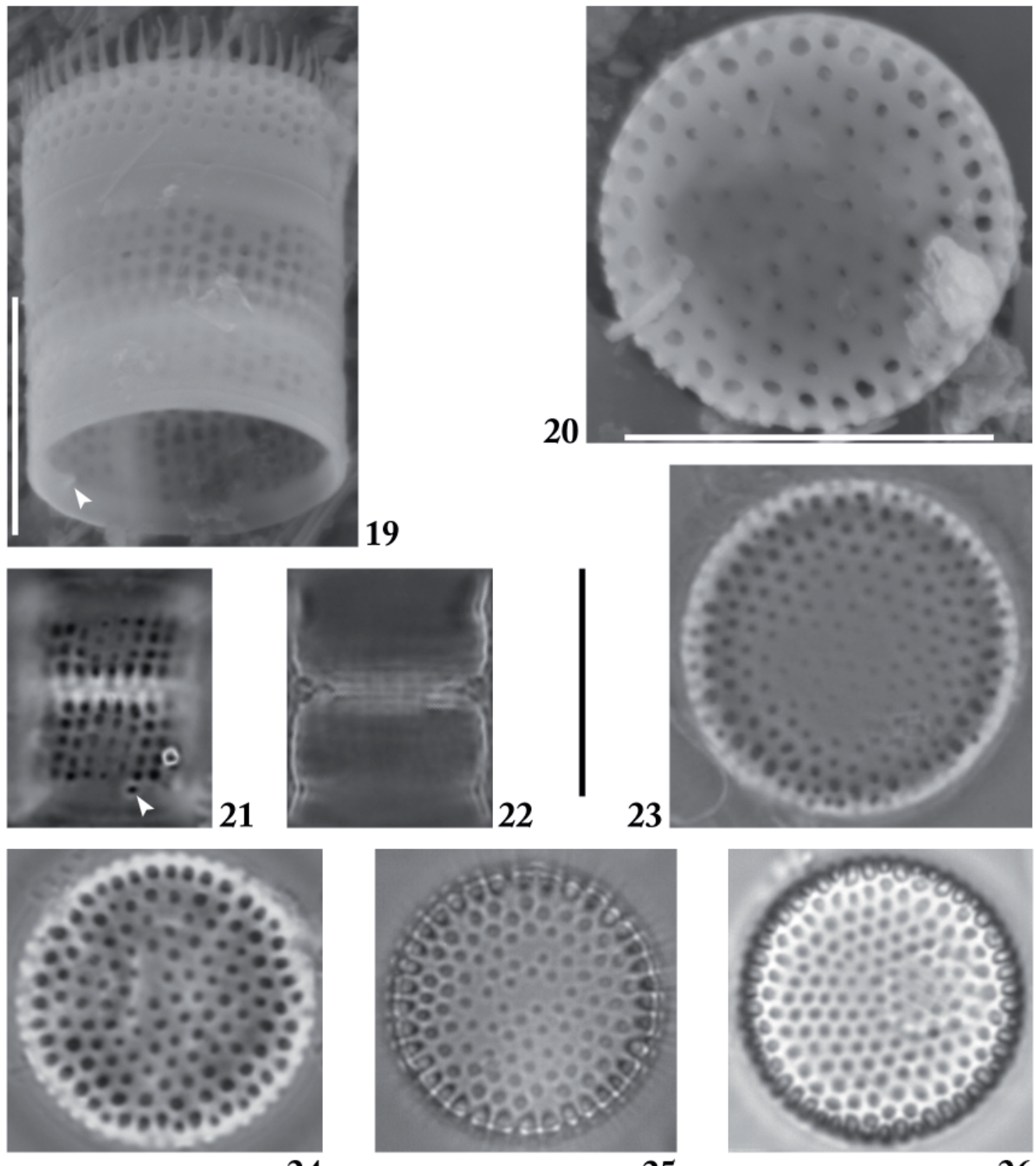

23

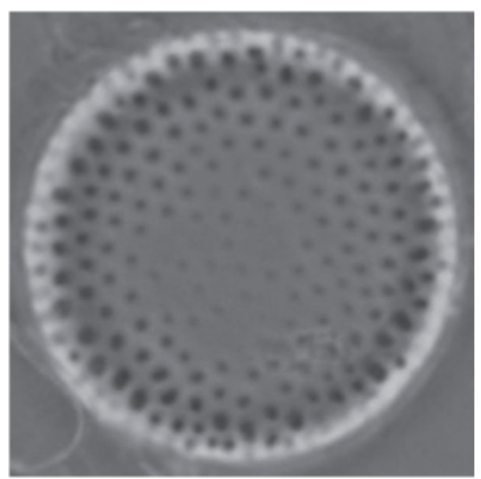

\section{4}

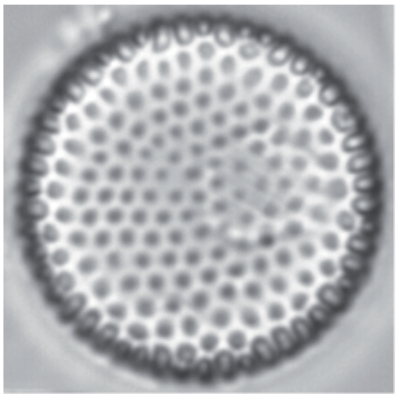

Figs 19-26. Aulacoseira pfaffiana (Reinsch) Krammer. - Fig. 19: SEM, mantle view, rimoportula, s. 1550; Fig. 20: SEM, valve view, s. 1630; Fig. 21: mantle view, rimoportula, inverted image, LM, 1600×, s. 1490; Fig. 22: cross section of Fig. 21, inverted image, LM, 1600×, s. 1490; Fig. 23: valve view, inverted image, LM, 1600×, s. 1560; Fig. 24: valve view, inverted image, LM, 1600×, s. 1680; Fig. 25: valve view, normal image, LM, 1500×, s. 1640; Fig. 26: valve view, normal image, LM, $1500 \times$, s. 1490; scale bars $-10 \mu \mathrm{m}$. 
transverse row of areolae. At least one distinct rimoportula at the collar. Internal valve mantle outlines curved with mostly poorly developed ringleist.

Aulacoseira aff. tenella (Nygaard) Simonsen (Figs 27-39) - Rare species in the Prášilské Lake record. - Cells low cylindrical, valves 5.6-7.6 $\mu \mathrm{m}$ in diameter, valve mantles 2.5-5.3 $\mu \mathrm{m}$ high in material from Prášilské Lake. Valve face covered with fine areolae, often shaded in the middle. Areolae at the valve face margin more distinct. Valve mantle with longitudinal rows of areolae becoming larger towards the valve face. Transverse row of distinctly larger areolae near the valve face margin followed by $2-3$ rows of finer areolae. Spines broadly triangular, protruded from each mantle rib.

Aulacoseira valida (Grunow) Krammer - Common in the Prášilské Lake record, large celled, characteristic form according to published description (Houk 2003).

There are several protocols for counting procedures for benthic diatoms (e.g. EN 2004, KELLY et al. 2012) but fewer guides are available for palaeoecological assessments (BATtARBEe 1986, et al. 2001; SERIEYssol 2010). Here we summarize the main points for the diatom analysis that will be used in EUROPIA project.

The fundamental approach for determination is not only finding differences in characteristics but also considering these characteristics as mosaic, in which not every component is always present. This method of compromises proved to be necessary in efforts to cope with the Aulacoseira distans species complex, furthermore the discrepancies in classification are widespread.

Detailed analysis of diatom assemblages in each sample and classification of taxa at first in the context of one sample enable to develop borders in characteristics further used throughout the sedimentary profile. Preliminary thorough taxonomic examination of the samples assists in the distinction of problematic taxa that requires relative comparison of specimens present in the assemblage instead of a valve by valve classification during the counting. In our opinion, specimens gained this way represent better the local diatom succession than taxa forcibly created within stated borders. The difficulty of matching our categories with taxa provided in training datasets naturally remains, but we avoid bias of false units.

We suggested counting the valve face views and the valve mantle views separately, in order to repair subsequent potential misidentifications more simply. Partly the reason for this approach can be problems with distinction of taxa mostly from one view (e. g. $A$. nivalis vs. $A$. pfaffiana from the mantle view, $A$. aff. tenella and $A$. perglabra from the valve face view), partly we have to keep in mind rare taxa merging characteristics of more common taxa (e.g. Aulacoseira sp. 2, pl. 39 in Houk (2003)). 
Despite all endeavours, distinguishing some taxa belonging to the Aulacoseira distans species complex using LM in Prášilské Lake is impossible and a classification into the aggregates is sometimes needed. Moreover, every Aulacoseira distans species complex taxon available in EDDI (European Diatom Database; JugGins

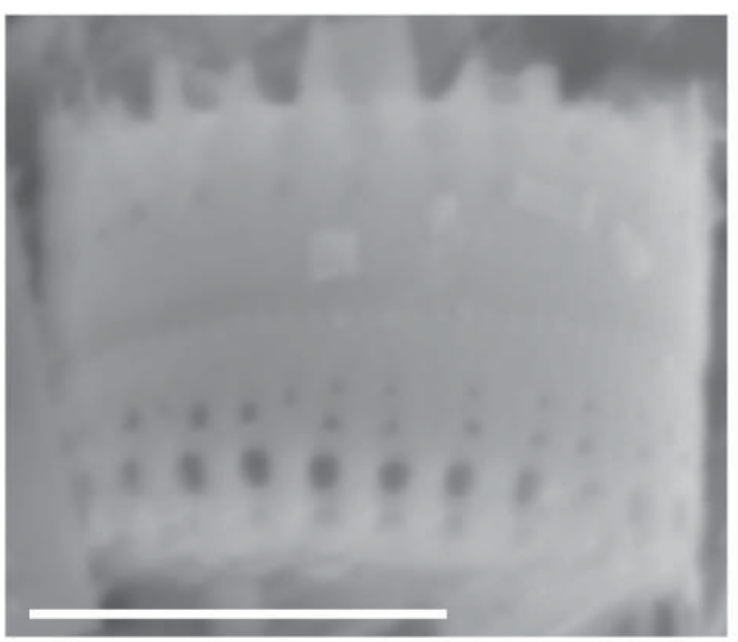

27

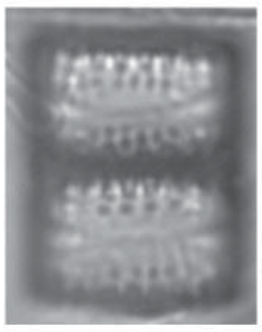

29

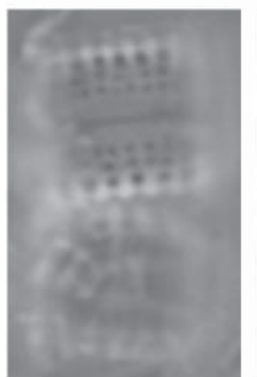

34

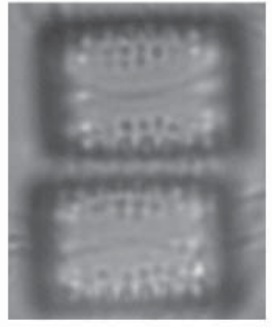

30

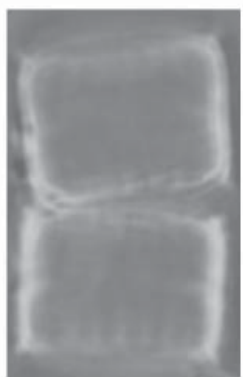

35

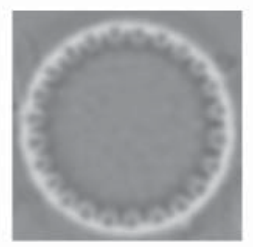

36

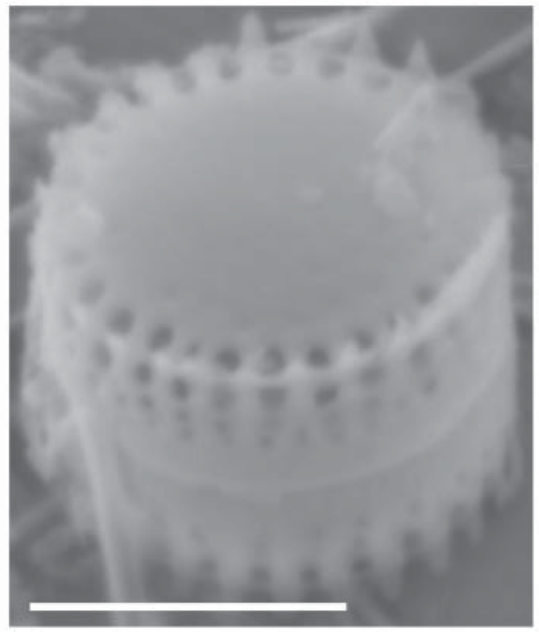

28

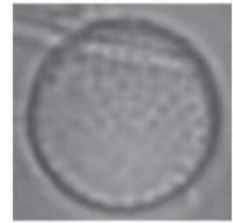

32

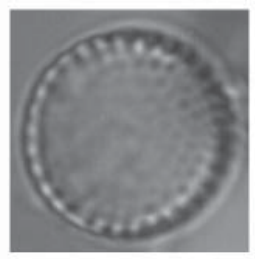

33

31

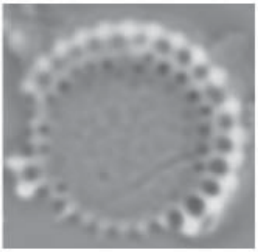

37

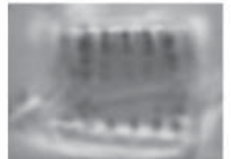

38

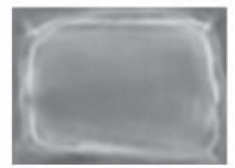

39

Figs 27-39. Aulacoseira aff. tenella (Nygaard) Simonsen. - Figs 27-28: SEM, s. 1550; Fig. 27: mantle view, Fig. 28. semi-valve view; Fig. 29-33: normal image, LM, 1500×, s. 1520; Figs 29-31 mantle view; Figs 32-33: valve view; Fig. 34-39: inverted image, LM, 1600×; Fig. 34: mantle view, s. 1560; Fig. 35: cross section of Fig. 34; Fig. 36: valve view, s. 1560; Fig. 37: valve view, s. 1590; Fig. 38: mantle view, s. 1590; Fig. 39: cross section of Fig. 38; scale bars: SEM - $5 \mu \mathrm{m}, \mathrm{LM}-10 \mu \mathrm{m}$. 
2001) hardly corresponds with taxa as they are defined regionally. Figures for $A$. pfaffiana in EDDI are missing and figures provided for $A$. nivalis correspond more probably with $A$. pfaffiana of our concept. Aggregates merging both of them or all into $A$. distans forms enable at least their utilization in transfer functions. $A$. aff. tenella could be put only in the $A$. distans aggregate, because our concept contradicts using the category $A$. distans var. tenella available in EDDI. Regardless of this constrained merging, the differentiation of as much forms as possible contributes to the discovery of the changes in the development of diatom communities.

\section{Aulacoseira nivalis and Aulacoseira pfaffiana case}

Many characteristics marking $A$. nivalis (or rather the earlier used name: $A$. distans var. nivalis (W. Smith) Haworth) off from $A$. pfaffiana are dispersed in the literature. Some of them remain important for distinction, while others have been considered less decisive. The pattern of areolae at the valve face is the example from the first group. The tangential rows of quite large areolae were originally mentioned as typical feature separating $A$. nivalis from $A$. distans (SMITH 1856; KRAMMER 1991). This structure of areolae also represents the basic characteristic of $A$. nivalis found in Prášilské Lake. The shape of areolae itself could be confusing, particularly the focus plays an important role in evaluation. Take note of conspicuous difference observable between inverted images (compare Figs 17-18 with Figs 23-24), whereas the normal images are unconvincingly distinct (compare Fig. 16 with Figs 25-26).

Two types of areolae (rounded in the centre and elongated at the edge) on the valve face of $A$.pfaffiana are considered to be important characteristic of this taxon (Tuji and Williams 2006). Although the majority of specimens demonstrated the typical pattern, this detail was not taken in account as the key feature for distinction from $A$. nivalis.

The arbitrary boundary of the number of areolae in a row on the mantle can be possibly established, but it does not seem to be a suitable character for identification (Tuji 2010). Moreover, if we accept this boundary from the mantle view, it is still impossible to make any reasonable boundary from the valve view and it is unacceptable for quantitative analyses. Thus other features are required from the mantle view like shape of areolae, presence of rimoportulae or shape of internal cell walls in cross-section.

Elongated square-shaped areolae at valve mantle were described as characteristic of $A$. pfaffiana (Houk 2003; Krammer and LANGe-Bertalot 1991). Nevertheless, we found a hint of prolongation both at $A$. nivalis and $A$. pfaffiana. Moreover, what we consider as $A$. nivalis in our material has more distinctly squareshaped areolae, which corresponds with overall areolae pattern on its valve. 
TUJi and Williams (2006) found during the examination of the type material of $A$.pfaffiana one rimoportula near the pseudoseptum well-visible using LM. TUjI (2010) later concluded that at least one rimoportula is present on the collar of valves in the type material of Melosira nivalis W. Smith. Because he presented at the same time intention to synonymy of $A$. pfaffiana (Reinsch) Krammer and $M$. nivalis, we did not consider rimoportulae as reliable feature to distinguish them in this state of knowledge. On the other hand, distinct rimoportulae were observed only at valves assigned to $A$. pfaffiana in the material from Prášilské Lake. More material should be examined to conclude anything about the number and presence of rimoportulae, it will be useful evidence to rely on.

Poorly developed ringleist is definitely one of the main characteristics separating $A$. nivalis from $A$. distans having deep ringleist (Houk 2003). Unfortunately, the ringleist of $A$. pfaffiana is also shallow, although it seems at least visible in comparison with non-evident ringleist of $A$. nivalis from the Prášilské Lake material.

The distinction between $A$. nivalis and $A$. pfaffiana remains the most problematic in the context of Prásilské Lake and what is more their abundance in this lake enhances the importance of a clear approach to distinguish them. Thus the differential analysis of $A$. nivalis and $A$. pfaffiana observed in Prášilské Lake were created taking all accessible approaches into account.

\section{Differential analysis of Aulacoseira nivalis and A.pfaffiana}

$A$. nivalis is distinguishable from $A$. pfaffiana because of the different pattern of areolae both on the valve face and the valve mantle. $A$. nivalis has rather larger areolae in the valve face centre and rather elongated areolae on the valve mantle arranged in shorter rows, whereas $A$. pfaffiana has areolae indistinct or missing in the valve face centre and rather rectangular areolae on the valve mantle arranged in longer rows. In cross section, $A$. nivalis completely lacks a ringleist, whereas $A$. pfaffiana has at least a rudimental one. At least one rimoportula well visible using LM is present at the collar of $A$. pfaffiana, whereas the rimoportula visible using LM in the valves of $A$. nivalis was not observed in our material.

Differential analysis of Aulacoseira nivalis/A. pfaffiana and other related taxa

Aulacoseira perglabra is easily distinguishable from $A$. nivalis and $A$. pfaffiana by the lack of areolae on the valve mantle and shaded central part of areolated valve face.

In some cases $A$. nivalis or $A$. pfaffiana can be confused with $A$. lirata, however, $A$. lirata has rows of distinct large areolae on the valve mantle, distinct ringleist, smooth valve face and noticeably thicker cell walls. 


\section{Nomenclature of Aulacoseira nivalis and A.pfaffiana}

There are problems not only with the distinction but also with nomenclatural priority in case of $A$. nivalis and $A$.pfaffiana. PотAPova et al. (2008) suggested synonymy of $A$. distans var. nivalis (W. Smith) Haworth and $A$.pfaffiana (Reinsch) Krammer after the revision of material from US lotic waters and referred to confusing similarity of specimens presented in KRAMMER and LANGE-BERTALOT (1991). Although we also consider pictures in KRAMMER and LANGE-BERTALOT (1991) not sufficient for the distinction of these forms, we do not follow the approach of merging them together (ENGLISH and Potapova 2009; PotA POVA et al. 2008; TUJi 2010). However, we are aware of nomenclatural problems (TUJI 2010) and thus we decided to use both taxa in species rank, i.e. Aulacoseira nivalis (W. Smith) English \& Potapova and A. pfaffiana (Reinsch) Krammer.

\section{Aulacoseira aff. tenella case}

Tiny low-mantle specimens in our samples are the most similar to $A$. tenella (Nygaard) Simonsen in Houk (2003). Although forms presented as A. tenella in several studies (e.g. Eloranta 1986; Genkal and Chekryzheva 2011; Potapova et al. 2008; Siver et al. 2005; TUji 2015) do not correspond with character of our valves, we decided to use the name $A$. tenella in the sense of pictures presented in Houk (2003), Tab. 37, Figs 10-18 (not presented there in the text part). Moreover, valves observed by Houk (2003) had originated from the sediments of lakes in the Bohemian Forest, i.e. from the same region where Prášilské Lake is situated. This fact confirmed us in the approach that our specimens are conspecific with those pictured in Houk (2003). Naturally, more effort should be invested to establish appropriate taxonomic category, but at this point, we consider adequate to connect it with current regional concept.

\section{Context of the Bohemian Forest}

Aulacoseira specimens dominated in the sedimentary record also in other lakes in the area, as follows from previous studies conducted at Černé ( ̌̌EHÁKOVÁ 1991), Čertovo (VESELÝ et al. 1993) and Plešné Lake (ŠTEFKovÁ 2008). К̌EHÁKOVÁ (1991) considered Aulacoseira as the dominant genus, while VESELÝ et al. (1993) reported Melosira distans var. nivalis as the dominant taxon. The last study focusing on subfossil diatoms from the Bohemian Forest lakes is the work of ŠTEFKOVÁ (2008) summarizing the development of diatom assemblages in Plešné Lake - the sole mesotrophic lake in the area. A. distans and $A$. pfaffiana were recorded as abundant, $A$. distans var. nivalis was present in several zones as dominant species. Unfortunately, pictures of valves from the 
Plešné Lake core were not published, thus comparison of approaches require more efforts. The reinvestigation of Plešné Lake slides would be useful, in order to elucidate several discrepancies. First of all the presence of $A$. distans along the whole Plešné Lake profile is remarkable, because we did not observe it in the material from Prášilské Lake and considered $A$. distans (Ehrenberg) Simonsen to be extinct (CRAWFORD and LiKhoshWAY 1999). As against palaeolimnological studies lacking any pictures, the Atlas by Houk (2003) provides extensive set of figures taken among others from sedimentary profiles from the Bohemian Forest lakes.

The representatives of Aulacoseira genus are the most abundant and common members of the diatom assemblages during the Holocene in Prášilské Lake and their dominant role in the sedimentary record of other Bohemian Forest lakes is documented by previous studies. The dominance of Aulacoseira taxa and especially the high abundance of members of the Aulacoseira distans species complex in diatom records obtained from the Bohemian Forest lakes are an appreciation of the necessity of taxonomic harmonization of this group in the region. This study consequently aimed to specify the attitude towards the determination of this dominant diatom assemblage component. The species rank concept is accepted after the detailed analysis of the similar and related taxa of the Aulacoseira distans species complex. All delimited taxa will be distinguished during the counting procedure, in order to produce harmonized data for further palaeoecological reconstructions.

High-resolution diatom analyses are in progress for the palaeoecological reconstruction based on sediments from the Czech glacial lakes. The examination of their sediments has a great potential in the research of environmental changes, but further analysis must be based on reliable data. The assignment of a unified approach to the determination of these problematic taxa is the suitable way for subsequent correlation of the results. The harmonization at the regional level is naturally only the first step, next revisions should follow to improve training datasets used for palaeoenvironmental reconstructions.

Acknowledgements - This study was planned and partly carried out during the two-month traineeship of Anna Tichá supported by Erasmus program. A special thank goes to Katalin Báldi, formal supervisor during the traineeship. We are very grateful to referees for their useful advices and suggestions to the manuscript. The study was originated in the scope of the project EUROPIA (GACR 16-06915S) of the Czech Science Foundation and the student's project (GAUK 1418217) funded by the Charles University Grant Agency. This work was also supported by the institutional long-term research development project No.AV0Z60050516 funded by the Academy of Sciences of the Czech Republic. The background of microscopic work was supported by the National Research, Development and Innovation Office - NKFIH (OTKA 119208, CRYPTIC project) grant. 
Összefoglaló: A csehországi Prášilské tó Holocén kova közösségeiben az Aulacoseira nemzetség taxonjai gyakran dominánsak. A tavi üledék vizsgálata során a nemzetség fajainak itt bemutatott részletes összehasonlító elemzésének célja, hogy megbízható alapot biztosítson a tervezett paleoökológiai rekonstrukciókhoz. A nemzetség kilenc faját különböztettük meg a tóban. Ezek közül hat jellegzetes bélyegeket visel ( $A$. alpigena, A. lacustris, A. laevissima, A. lirata, A. perglabra, $A$. valida), a Prášilské tóban talált egyedek megegyeznek a fajleírásokkal, egymástól egyértelmüen megkülönbözethetőek. Ezzel szemben az $A$. nivalis formakörbe tartozó három faj ( $A$. nivalis, $A$. pfaffiana, $A$. aff. tenella) megkülönböztetése nem egyértelmü. Ezeknél a fajoknál a bélyegek egymással átfedőek, és annak ellenére, hogy összevonásukra történtek javaslatok, úgy döntöttünk, hogy faji szinten megkülönböztetjük, mint $A$. nivalis (W. Smith) English et Potapova, $A$. pfaffiana (Reinsch) Krammer, ill. $A$. aff. tenella. Ugyanakkor, a fénymikroszkópos, rutin számolás során e három taxon faj szintủ határozása nem megbízható, ezért ezeket együtt célszerű kezelni. Kiegészítő vizsgálat szükséges az együtt előforduló fajok arányainak megállapítására, ami kiterjed a felső- (valva face) és az oldalnézetre (mante view).

\section{REFERENCES}

Battarbee, R. W (1986): Diatom analysis. - In: Berglund, B. E (ed.): Handbook of Holocene palaeoecology and palaeohydrology. Wiley, Chichester, pp. 527-570.

Battarbee, R. W., Jones, V. J., Flower, R. J., Cameron, N. G., Bennion, H., Carvalho, L. and Juggins, S. (2001): Diatoms. - In: SMOL, J. P., Birks, H. J. B. and LAst, W. M. (eds): Tracking environmental change using lake sediments. Vol. 3, Terrestrial, algal, and siliceous indicators. Springer Netherlands, pp. 155-202.

BIRKs, H. J. B., (2010): Numerical methods for the analysis of diatom assemblage data. - In: SMOL, J. P. and STOERMER, E. F. (eds): The diatoms: applications for the environmental and earth sciences. 2nd ed., Cambridge University Press, Cambridge, pp. 23-54.

Buczkó, K., Ognjanova-Rumenova, N. and Magyari, E. (2010): Taxonomy, morphology and distribution of some Aulacoseira taxa in glacial lakes in the south Carpathian Region. Polish Bot. J. 55: 149-163.

CRAWFORD, R.M. and Li KHOSHWAY, Y. (1999): The frustule structure of original material of Aulacoseira distans (Ehrenberg) Simonsen. - Diatom Res. 14: 239-250. https://doi.org/10.1080/0269249X.1999.9705468

Eloranta, P. (1986): Melosira distans var. tenella and Eunotia zasuminensis, two poorly known planktonic diatoms in finnish lakes. - Nordic J. Bot. 6: 99-103.

https://doi.org/10.1111/j.1756-1051.1986.tb00865.x/full

EN 14407, 2004. Water quality: guidance standard for the identification, enumeration and interpretation of benthic diatom samples from running waters.

English, J. and Potapova, M. (2009): Aulacoseira pardata sp. nov., A. nivalis comb. nov., A. nivaloides comb. et stat. nov., and their occurrences in Western North America. - Proceedings of the Academy of Natural Sciences of Philadelphia, pp. 37-48.

Genkal, S. I. and ChekryzheVA, T. A. (2011): Centric diatoms (Bacillariophyta, Centrophyceae) in Karelian Waterbodies. - Inland Water Biol. 4(1): 1-11. https://doi.org/10.1134/S199508291101007X

Genkal, S. I. and Kulikovskiy, M. S. (2014): Centric diatoms from Lake Frolikha (Transbaikal Area) and peculiarities of distribution of some taxa in Asia. - Inland Water Biology 7(3): 201-210. https://doi.org/10.1134/s1995082914030079

Houk, V. (2003): Atlas of freshwater centric diatoms with a brief key and descriptions, Part I. Melosiraceae, Orthoseiraceae, Paraliaceae and Aulacoseiraceae. - Czech Phycol. Suppl. 1: 1-27. 
Houk, V. and KleE, R. (2007): Atlas of freshwater centric diatoms with a brief key and descriptions, Part II. Melosiraceae and Aulacoseiraceae (Supplement to Part I). - Fottea 7: 85-255.

Juggins, S. (2001). The European diatom database. User guide, Version, 1. - http://craticula.ncl. ac.uk/Eddi/jsp/help.jsp [accessed: 15.09.2017]

Kelly, M. G., Gómez-Rodríguez, C., Kahlert, M., Almeida, S. F., Bennett, C., Bottin, M., Delmas, F., Descy, J. P., Dörflinger, G., Kennedy, B. and Marvan, P. (2012): Establishing expectations for pan-European diatom based ecological status assessments. - Ecol. Indicators 20: 177-186. https://doi.org/10.1016/j.ecolind.2012.02.020

Krammer, K. (1991): Morphology and taxonomy in some taxa of the genus Aulacoseira Thwaites (Bacillariophyceae). I, Aulacoseira distans and similar taxa. - Nova Hedwigia 52: 89-112.

Krammer, K. and Lange-Bertalot, H.(1991): Bacillariophyceae, 3. Teil: Centrales, Fragilariaceae, Eunotiaceae. - In: Ettl, H., Gerloff, J., Heynig, H., Mollenhauer, D. and Al, E. (eds): Süßwasserflora von Mitteleuropa (Band 2/3). Gustav Fischer Verlag, Jena, 576 pp.

Mentlík, P., MináR, J., BŘízová, E., Lisá, L., TÁboří́, P. and STACKe, V. (2010): Glaciation in the surroundings of Prášilské Lake (Bohemian Forest, Czech Republic). - Geomorphology 117: 181-194. https://doi.org/10.1016/j.geomorph.2009.12.001

Nedbalová, L., Vrba, J., Fott, J., Kohout, L., Kopáček, J., Macek, M. and Soldán, T. (2006): Biological recovery of the Bohemian Forest lakes from acidification. - Biológia 61: 453-465. https://doi.org/10.2478/s11756-007-0071-y

Pota Pova, M. (2014): Diatoms of Bering Island, Kamchatka, Russia. - Nova Hedwigia 143: 63-102. https://doi.org/10.1127/1438-9134/2014/004

Potapova, M. G., Bixby, R. J., Charles, D. F., Edlund, M. B., Enache, M. E., Furey, P., Hamilton, P. B., Lowe, R. L., Manoylov, K. M., Ognjanova-Rumenova, N. and Ponader, K. C. (2008): Eighteenth NAWQA workshop on harmonization of algal taxonomy-representatives of the genus Aulacoseira Thwaites in NAWQA samples. - The Academy of Natural Sciences of Philadelphia, Philadelphia, 53 pp.

ŘEHÁ KOVÁ, Z. (1991): The preliminary report on the study of diatoms of Černé Lake in Šumava. (Předběžná zpráva o studiu diatom Černého Jezera na Šumavě). - Geosci. Res. Rep. 1990: 131-133.

Serieyssol, K., Chatelard, S. and Cubizolle, H. (2010): Diatom fossils in mires: a protocol for extraction, preparation and analysis in palaeoenvironmental studies. - Mires and Peat 7: 1-11.

Siver, P. A. and KLING, H. (1997): Morphological observations of Aulacoseira using scanning electron microscopy. - Can. J. Bot. 75: 1807-1835. https://doi.org/10.1139/b97-894

Siver, P. A., Hamilton, P. B., Stachura-Suchoples, K. and Kociolek, J. P. (2005): Diatoms of North America. The freshwater flora of Cape Cod. - In: LANGE-BERTALOT, H. (ed.): Iconographia Diatomologica Vol. 14. A.R.G. Gantner, 463 pp.

Smith, W. (1856): Synopsis of British Diatomaceae. Vol. 2. - John Van Voorst, London, 107 pp.

Stoermer, E. F. (2001): Diatom taxonomy for paleolimnologists. - J. Paleolimnol. 25(3): 393-398.

ŠoBR, M. and JANSKÝ, B. (2016): The morphometric parameters of glacial lakes in the Bohemian Forest. - Silva Gabreta 22: 31-61.

ŠTEF KOVÁ, E. (2008): Diatom species composition in the sediment core of Plešné Lake (Bohemian Forest, Czech Republic). - Silva Gabreta 14:73-84.

TujI, A. (2010): Examination of type material of Melosira nivalis W. Sm. (Bacillariophyceae) and its synonymy with Aulacoseira pfaffiana (Reinsch) Krammer. - Bull. Nat. Mus. Nature and Science, Ser. B 36: 161-64.

Tuji, A. (2015): Distribution and taxonomy of the Aulacoseira distans species complex found in Japanese harmonic artificial reservoirs. - Bull. Nat. Mus. Nature and Science, Ser. B 41(2):53-60. 
Tuji, A. and Williams, D. M. (2006): Examination of type material for Aulacoseira pfaffiana (Bacillariophyceae) with special reference to the position of its rimoportula. - Bull. Nat. Sci. Mus., Tokyo, Ser. B 32:117-121.

Veselý, J., Almquist-Jacobson, H., Miller, L. M., Norton, S. A., Appleby, P., Dixit, A. S. and SMOL, J. P. (1993): The history and impact of air pollution at Čertovo Lake, southwestern Czech Republic. - J. Paleolimnol. 8: 211-231. https://doi.org/10.1007/BF00177857

VRba, J., KopáČEK, J., TAhovsKÁ, K. and ŠANTRŮČKOVÁ, H. (2015): Long-term ecological research of glacial lakes in the Bohemian Forest and their catchments. - Silva Gabreta 21: 53-71.

(submitted: 19.09.2017; accepted: 28.11.2017) 